\title{
California's agritourism operations expand despite facing regulatory challenges
}

\author{
Surveys show that agritourism operators in California need increased support from their local \\ governments and the state regarding regulatory requirements.
}

Shermain Hardesty, Emerita Extension Economist, Department of Agricultural and Resource Economics, UC Davis

Penny Leff, Statewide Agritourism Coordinator, Sustainable Agriculture Research and Education Program, UC ANR

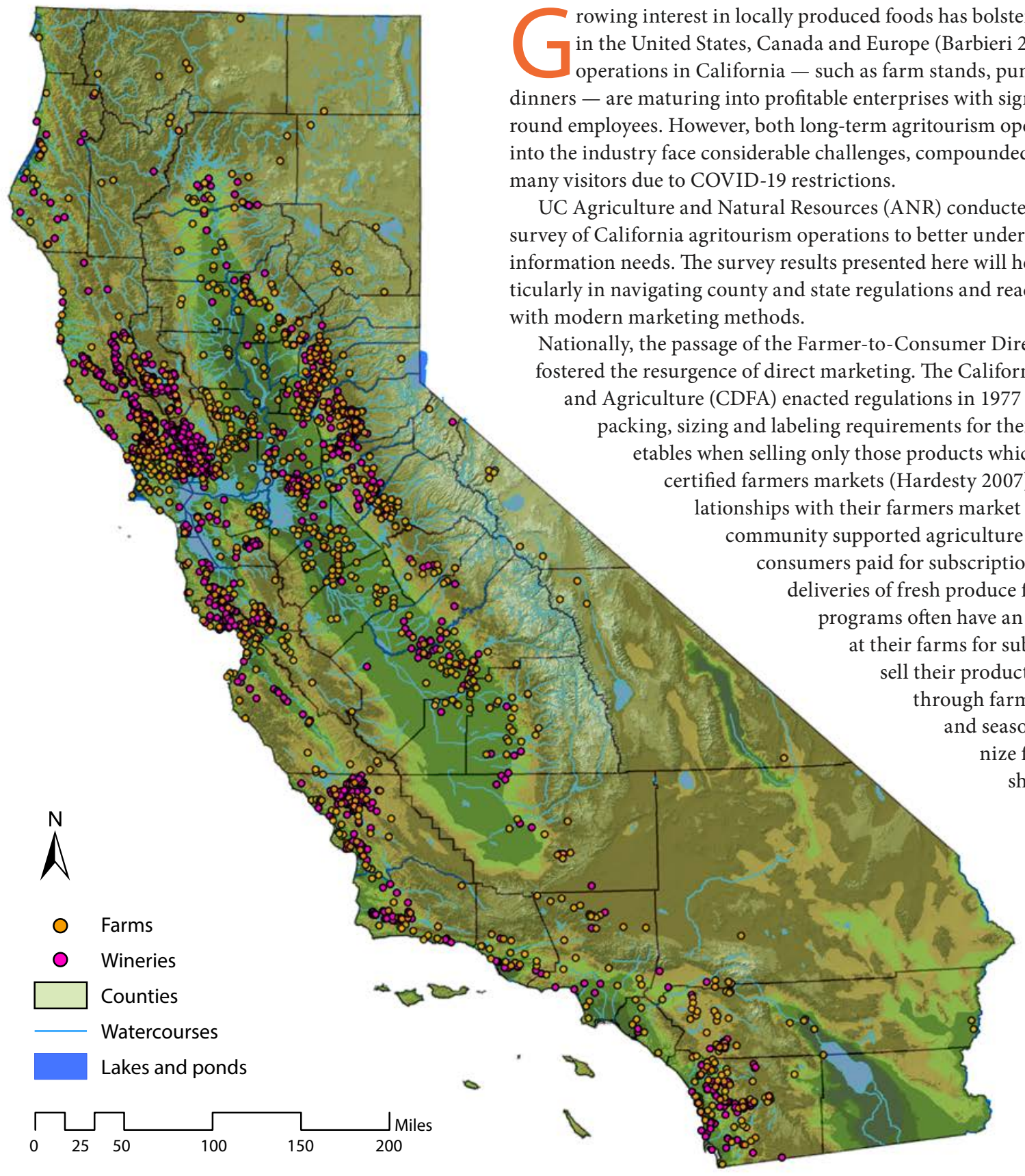

rowing interest in locally produced foods has bolstered demand for agritourism in the United States, Canada and Europe (Barbieri 2013). Many agritourism perations in California - such as farm stands, pumpkin patches and farm dinners - are maturing into profitable enterprises with significant revenue and yearround employees. However, both long-term agritourism operators and new entrants into the industry face considerable challenges, compounded by the inability to host many visitors due to COVID-19 restrictions.

UC Agriculture and Natural Resources (ANR) conducted its second statewide better understand their challenges and information needs. The survey results presented here will help to target outreach, parand reaching potential customers modern marketing methods.

Nationally, the passage of the Farmer-to-Consumer Direct Marketing Act of 1976 ostered the resurgence of direct marketing. The California Department of Food 977 that exempt farmers from king, sizing and labeling requirements for their fresh fruits, nuts and vegtables when selling only those products which they grow themselves at rtified farmers markets (Hardesty 2007). As farmers developed reionships with their farmers market customers, many initiated mmunity supported agriculture (CSA) programs, in which 列 programs often have annual or bi-annual event at their farms for subscribers. Many farms also ll their products directly to consumers rough farm stands, U-pick operations d seasonal festivals. Some orgaze farm dinners, tours, workshops, demonstrations and children's day camps, or offer their farms as wedding or retreat facilities, and some have even developed farmstay programs

California agritourism and winery operations. Data collected and map produced in May 2015 by the UC Small Farm Program. 


\section{UC ANR's agritourism efforts}

The University of California's Small Farm Program (SFP) began supporting agritourism in the mid-1990s with two purposes: (1) enhance the economic viability of smaller-scale farms by diversifying their market channels; and (2) connect the urban population to agriculture. It defined agritourism as "any incomegenerating activity conducted on a working farm or ranch for the enjoyment and education of visitors". In a 1999 newsletter, the then-director, Desmond Jolly, noted that agritourism involves linking agriculture to consumers, which "... requires a new set of skills that are somewhat different from those typical of more conventional agriculture." In 2000, the SFP launched its CalAgTour.org website, which continues on today to provide a searchable directory of 767 agritourism operations across the state, along with a calendar of agritourism events. Farms can list their agritourism operations on CalAgTour.org at no cost. In 2011, the then-leaders of the UC ANR Agritourism Work Group, UC ANR Advisors Holly George and Ellie Rilla, published the second edition of the UC ANR handbook Agritourism and Nature Tourism in California, which has been distributed extensively to participants at UC ANR agritourism workshops.

\section{Surveys of California agritourism operations}

The SFP conducted the first statewide survey of agritourism operations in 2009 after compiling a list of 1,940 potential agritourism operations. The overall

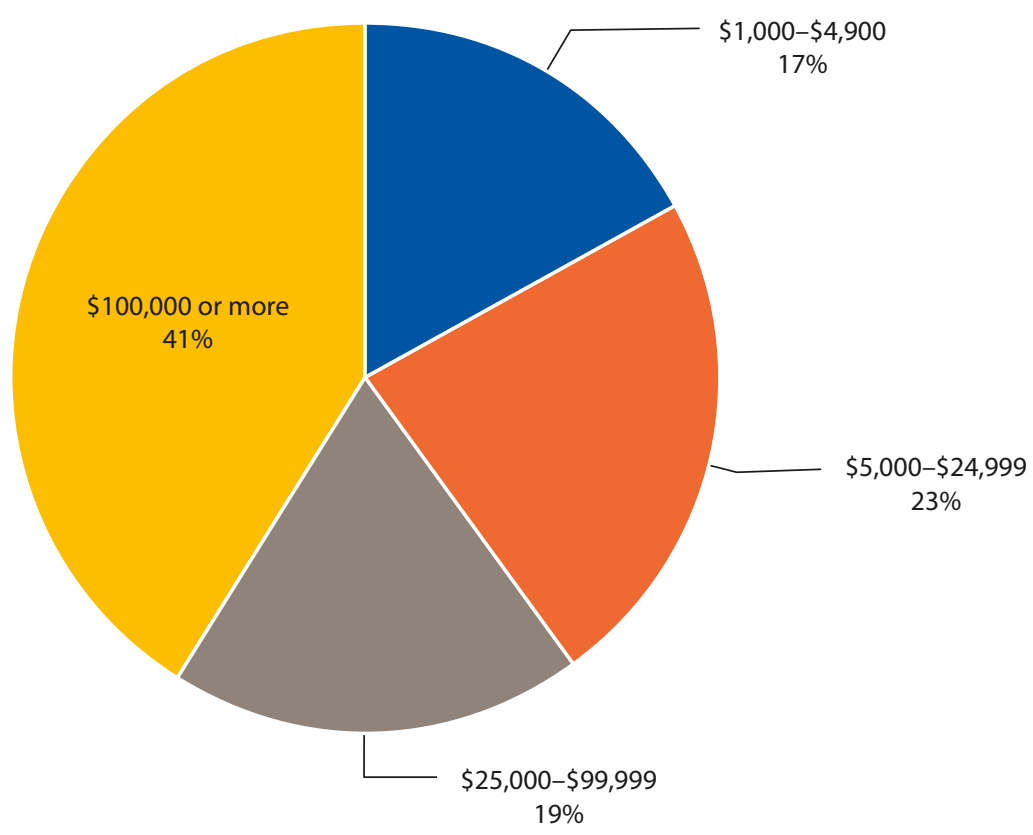

FIG. 1. Agritourism revenue distribution among agritourism operations (percent of respondents earning $\$ 1,000$ or more). purpose of the survey was to provide data for determining agritourism extension program priorities, by quantifying the extent of agritourism activities and identifying major opportunities and challenges that agritourism operators are facing. The results were published in 2011 in this journal (Rilla et. al. 2011).

In 2015, the SFP partnered with Colorado State University on a USDA National Institute for Food and Agriculture project to conduct a similar survey of agritourism operations in both states. A list of more than 2,000 potential agritourism operations in California was compiled. From this list, 750 nonwinery operations and 500 winery operations were randomly selected to be surveyed. The questionnaire was mailed in March 2015; an online survey was also sent.

The following information relates to the 164 respondents who indicated that they generated revenue of at least $\$ 1,000$ from their agritourism operation in 2014. The lack of a comprehensive database of agritourism operations in California continues to be a barrier to analyzing the representativeness of the survey respondents.

Like California agriculture in general, agritourism operators tend to be older than the general population; $55 \%$ were between the ages of 46 and $65,28 \%$ were 66 or older, $15 \%$ were between 26 and 45 years old, and $2 \%$ were 25 years old or younger. Ninety-three percent had some college education, with over a quarter of the respondents having graduate degrees. Forty-one percent of the operations were located on the coast, $31 \%$ in the Central Valley and 28\% in the foothill, mountain and desert regions.

Forty-one percent of the operations generated at least $\$ 100,000$ in gross annual agritourism revenue (fig. 1). This is a considerable increase from the $27 \%$ reported in the 2009 survey; most of the increase is probably attributable to the fact that $40 \%$ of the 2015 survey questionnaires were sent to wineries, which sell higher value product than most agritourism operations. Unfortunately, the number of winery respondents in the 2015 survey cannot be determined.

While more than one-third of the agritourism operations had been operating for 20 or more years, one-fourth were less than 5 years old. Experience tends to increase an agritourism operation's revenues; $47 \%$ of those with agritourism operations for 20 or more years earned at least $\$ 100,000$ in agritourism revenues, compared to only $25 \%$ of those operating less than 5 years.

Twenty-two percent of the operations were open between 101 and 250 days during 2014, while 37\% were open more than 250 days. Not unexpectedly, agritourism revenues tend to increase as the number of days they are open rises; two-thirds of the operations that were open more than 250 days generated at least $\$ 100,000$ in agritourism revenues while only two operations open 35 days or less earned at least $\$ 100,000$.

Most of the visitors to California's agritourism operations are local residents. Almost half (47\%) of the visitors were from the same county while one-fourth 
were from a neighboring county; $10 \%$ were from other states and $4 \%$ were from other countries.

Agritourism operations continue to offer a very diverse range of activities. Respondents were asked to indicate what percentage of their agritourism revenues came from each of the following five categories:

- On-farm direct sales (U-pick, farm stand, farm store selling fresh fruits, nuts, vegetables, herbs, nursery products, Christmas trees, flowers, meats, eggs or processed fruit or vegetable products, dairy, fibers, wine, beer, spirits, juices, oil, baked goods, soaps, lotions or any other products)

- Accommodations/lodging (farm stays, bed and breakfast inn, vacation rental, guest ranch, camping, cabins, yurts, sheep wagons)

- Entertainment/special events (weddings, farm dinners, family reunions, retreats, festivals, barn dances, corn or other mazes, haunted houses, sports events, games, concerts, pig races, pony rides, hay rides, train rides, etc.)

- Outdoor recreation (bicycle rides, picnicking, swimming, hunting, fishing, bird watching, photography, snowmobiling, horseback riding, skeet shooting)

- Educational activities (farm or ranch work experience, camps, classes, tours, tastings, demonstrations, workshops, petting zoos, egg gathering, etc.)

By far, the most frequently offered agritourism activity is direct sales of agricultural products, with $89 \%$ engaged in this activity; the next most popular activities were education (44\%) and entertainment/ special events (43\%). The least prevalent activities were accommodations (17\%) and outdoor recreation (12\%). Almost two-thirds (63\%) of respondents reported receiving $50 \%$ or more of their agritourism revenue from direct sales; this $50 \%$ threshold was used to define an operation's primary activity. Not surprisingly, direct sales were the most common primary activity (fig. 2). In addition to having a primary revenue source, most agritourism operations also offer other activities that attract customers and generate revenue. The newest entrants into the agritourism industry (less than 5 years old) are trending toward offering more experiencebased activities, such as entertainment/special events, education and accommodations, while the older agritourism operations are more likely to focus on direct marketing of their farms' products.

\section{Marketing and challenges}

Agritourism operations need to engage in marketing to attract visitors and generate revenues. The two most used marketing tools are also those that they rated as most effective - word of mouth and website (table 1). Social media has increasingly become a critically important promotion tool for agritourism operations (since this survey was conducted, it is highly likely that Facebook and Twitter have increased significantly in usage among agritourism operations). Social media experts have described how potential visitors usually search first using Google or YouTube, visit websites, Facebook pages or YouTube videos to learn about the operation, and then will still check out the reviews on TripAdvisor or Yelp. Increasingly, potential visitors use mobile devices to search, both at home and while traveling. The CalAgTour.org website was redesigned to be mobile responsive; it automatically resizes when used on a cell phone. During the year ending June 30, 2020, $43 \%$ of new CalAgTour.org visitors used a mobile device, whereas in the year ending June 30, 2014, only $20 \%$ of new visitors used a mobile device.

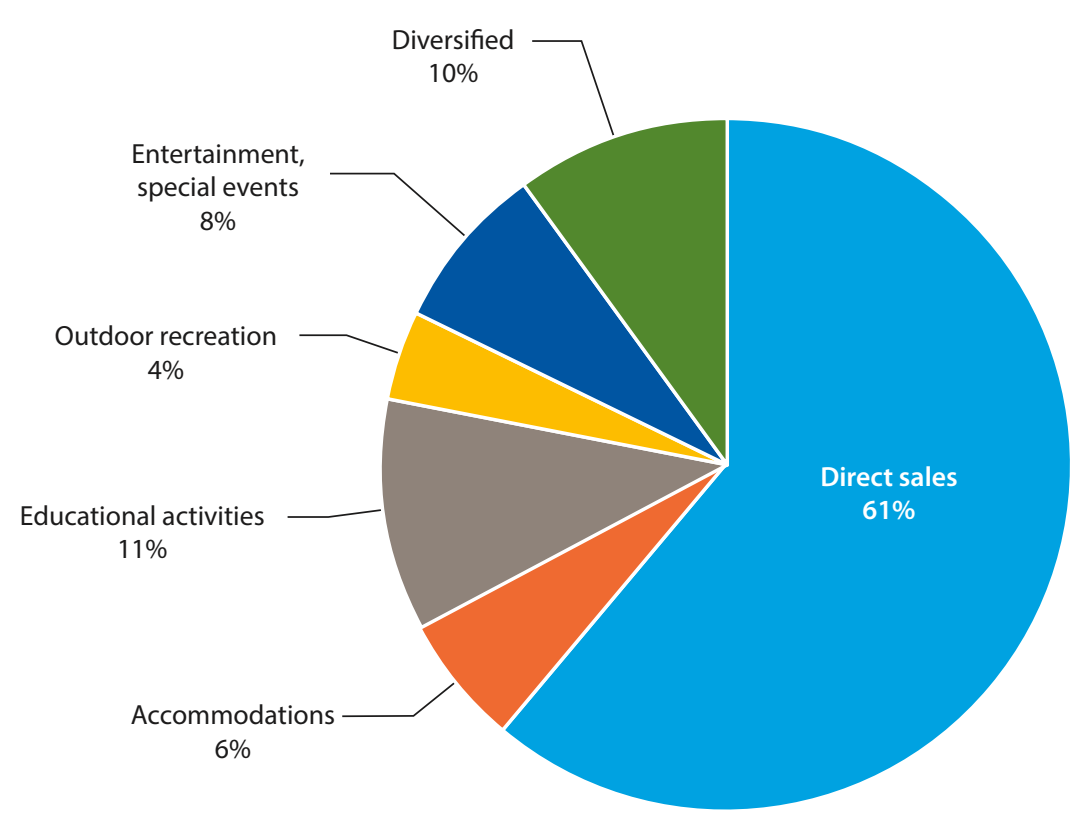

FIG. 2. Primary activity of California agritourism operations (percent of respondents).

TABLE 1. Marketing tools used by agritourism operations

\begin{tabular}{|l|l|l|}
\hline Marketing Tool & \% used & $\begin{array}{c}\text { \% rating very } \\
\text { effective }\end{array}$ \\
\hline Word of mouth & 98 & 64 \\
\hline Website & 95 & 42 \\
\hline Feature story & 85 & 37 \\
\hline Direct mail or email & 74 & 35 \\
\hline Referrals from other businesses & 92 & 32 \\
\hline Facebook and/or Twitter & 85 & 26 \\
\hline Farm or wine trail association & 81 & 26 \\
\hline Highway sign & 54 & 24 \\
\hline Sign outside business & 87 & 23 \\
\hline Trip Advisor and/or Yelp & 71 & 20 \\
\hline Paid advertising & 73 & 19 \\
\hline Regional or state tourism guide & 82 & 14 \\
\hline Print brochures, posters, fliers & 81 & 14 \\
\hline Chamber of commerce or visitor bureau referrals & 82 & 12 \\
\hline
\end{tabular}


Agritourism enables farms to diversify their revenue sources; however, this diversification can involve multiple challenges. The most significant challenges reported in 2015 by California's agritourism operators were similar to those in the 2009 survey. The challenge that was most frequently rated as "very challenging" in 2015 was "city/county permitting and zoning" (34\%), followed by "other state and local regulations" (28\%). In the same survey conducted in Colorado, these issues were considerably less problematic, with $17 \%$ and $19 \%$,

The preliminary findings from the 2019 National Agritourism survey also confirm that regulations are more challenging to California's agritourism operations than to those in other states.

respectively, of Colorado's agritourism operations reporting them as "very challenging” (Gaede et al. 2015).

The preliminary findings from the 2019 National Agritourism survey also confirm that regulations are more challenging to California's agritourism operations than to those in

other states (Chase et al., unpublished data). In that survey, $49 \%$ of California's agritourism operations reported that "city/county zoning and permitting" were "very challenging", compared to $23 \%$ of the agritourism operations nationwide. Similarly, $47 \%$ of California's agritourism operations reported that "state/local regulations" were "very challenging", compared to $28 \%$ of the agritourism operations nationwide. In California, counties differ considerably regarding the strictness/ cost of their zoning and permitting requirements, as well as how rigorously they enforce the state's environmental health regulations. County officials are often invited to attend UC ANR agritourism workshops, in an effort to promote dialog and understanding between regulators and agritourism operators.

The COVID-19 pandemic is the most recent challenge facing agritourism operations; many — including wineries - have canceled on-site activities and sales. On May 8, CDFA issued a detailed set of COVID-19 guidelines for farms with farm stands and U-pick operations (CDFA 2020). Nevertheless, the pandemic has also been described as generating a rebirth of the local farm movement. Demand for fresh local produce has increased as new customers are learning to cook instead of eating out (Hiller 2020). Numerous agricultural organizations have responded with ways to assist smaller-scale farms. F.E.E.D. Sonoma, a micro-regional food distributor, transformed itself from serving Bay Area restaurants into a CSA for Sonoma County residents. Sonoma County Farm Trails created an online portal to enable its members to market their products through the following channels: farm stands, CSAs accepting new members, local delivery and drop points, and online orders and delivery. The CalAgTour.org directory (UC ANR 2020) recently added a blog describing the responses of eight agritourism operations to the COVID-19 pandemic. Only one of the eight operations - a pumpkin farm in Contra Costa County — decided to temporarily close its agritourism operations for this fall. The others decided not to offer school tours in the fall. However, they are implementing social-distancing measures, as they promote their farms as safe family attractions in the outdoors.

\section{In conclusion}

Agritourism is an important component of California agriculture. UC ANR has been conducting agritourism research and outreach for almost 30 years. While agritourism enterprises are a viable source of diversification for California's farms and ranches, they also contribute to rural economies and educate the public about agriculture and the food that they eat. Some counties have added agritourism into their general plans. However, these survey results indicate that California's agritourism operations need increased support from their local governments and the state regarding regulatory requirements.

More information about agritourism in the western United States is available at: https:/ucanr.edu/sites/ agritourism and https://agritourism.localfoodeconomics.com. CA

This project was partially funded by USDA/AFRI Project \#2014-68006-21842.

\section{References}

Barbieri C. 2013. Assessing the sustainability of agritourism in the US: A comparison between agritourism and other farm entrepreneurial venture. J Sustainable Tourism (2):252-70. https://doi.org/10.1080/0 9669582.2012.685174

[CDFA] California Department of Food and Agriculture. 2020. Guidance for Farm Direct Sales and Pick-Your-Own Operations during COVID-19. www.cdfa.ca.gov/coronavirus/pdfs/GUIDANCEFarmDirectandPickYourOwnCOVID-19.pdf

Gaede D, Leff P, Hardesty S, et al. 2015. Influences affecting agritourism success in the western US.

https://agritourism.localfoodeconomics.com/wp-content/uploads/2016/02/NET-2015-Agritourism-Presentation-Final.pdf

Hardesty S. 2007. Role of direct marketing in California. ARE Update 10:3. https://giannini.ucop.edu/filer/file/1453327746/16737/
Hiller S. 2020. COVID-19 sparks a rebirth of the local farm movement. Yes Magazine. www.yesmagazine.org/environment/2020/05/21/ coronavirus-food-local-farm-movement/

Jolly D. 1999. Agricultural tourism: Emerging opportunity. Small Farm News. http://sfp.ucdavis.edu/pubs/SFNews/Summer99/emerge/ Rilla E, Hardesty SD, Getz C, George H. 2011. California agritourism operations are growing. Calif Agr 65(2):57-65. https://doi. org/10.3733/ca.v065n02p57

[UC ANR] UC ANR Sustainable Agriculture Research and Education Program. 2020. California agritourism operators share thoughts and plans for fall 2020. https://ucanr.edu/sites/agritourism/files/334779. pdf 